\title{
Analiza właściwości technologicznych zaczynów cementowych do uszczelniania rur okładzinowych w kawernowych magazynach gazu
}

\begin{abstract}
Magazynowanie gazu ziemnego może odbywać się na wiele sposobów, m.in. pod ziemią lub na jej powierzchni w specjalnych zbiornikach. Najbardziej popularną metodą jest wykorzystanie podziemnych magazynów gazu, a zwłaszcza magazynów w kawernach solnych. Uszczelnienie kolumn rur okładzinowych w pokładach solnych wymaga zastosowania specjalnie opracowanych receptur zaczynów cementowych, z których otrzymane kamienie cementowe będą się odznaczać podwyższoną odpornością na korozyjne działanie soli. Jednym z podstawowych wymagań koniecznych do sporządzenia odpowiednich receptur jest użycie solanki o pełnym nasyceniu jako wody zarobowej oraz wykorzystanie jej jako środowiska do sezonowania próbek kamieni cementowych. Opracowanie zaczynów cementowych spełniających powyższe kryteria wymaga podjęcia innowacyjnych badań laboratoryjnych nad doborem odpowiednich rodzajów środków chemicznych i materiałów uszczelniających. W wyniku przeprowadzonych badań laboratoryjnych opracowano receptury zaczynów cementowych na bazie solanki o pełnym nasyceniu jako wody zarobowej, które mogą znaleźć zastosowanie podczas uszczelniania kolumn rur okładzinowych w warunkach występowania pokładów soli $[5,6,8]$.
\end{abstract}

Słowa kluczowe: kamień cementowy, magazyn gazu, parametry mechaniczne, kawerny solne.

\section{An analysis of the technological properties of cement slurries for sealing a casing in gas storage caverns}

\begin{abstract}
Natural gas storage can be carried out in many ways, i.a., underground or on the surface in special tanks. The most common method is the use of underground gas storage, especially in salt caverns. Sealing casings in salt layers requires the use of specially developed cement slurries recipes, from which the received cement stones are characterized by an increased resistance to the corrosive effects of salt. One of the basic requirements necessary for the preparation of appropriate recipes, is to use the full saturated brine as mixing water and using it as an environment for the seasoning of cement stone samples. Development of cement slurries that meet the above criteria requires innovative tests on choosing the most appropriate types of chemicals and sealants. The aim of laboratory tests were to develop cement slurries, based on fully saturated brine as mixing water that can be used during sealing the casings in salt layers.
\end{abstract}

Key words: cement stone, gas storage, mechanical properties, salt caverns.

\section{Wprowadzenie}

Magazynowanie gazu może odbywać się na wiele sposobów. Pod powierzchnią ziemi wyróżnia się trzy główne rodzaje magazynów:

- w wyeksploatowanych złożach ropy i/lub gazu ziemnego,

- w warstwach wodonośnych,

- w kawernach solnych.
Budowa magazynu gazu w kawernach solnych jest bardziej kosztowna niż np. w wyeksploatowanych złożach ropy naftowej i/lub gazu ziemnego lub w warstwach wodonośnych. Jednakże taki magazyn gazu ma wiele cech pozytywnych. Głównymi zaletami magazynów w kawernach solnych są np. możliwości użycia wysokich mocy zatłaczania i odbioru gazu 
w stosunku do pojemności. Magazyny w kawernach zajmują również dużo mniejsze powierzchnie niż pozostałe rodzaje magazynów, a także istnieje w nich możliwość wielu cykli zatłaczania i odbioru gazu w ciągu roku. Jedną z większych zalet tworzenia magazynów gazu w soli jest ich elastyczność oraz płynność funkcjonowania dzięki możliwości szybkiego przejścia z zatłaczania na oddawanie i odwrotnie. Środowisko soli zapewnia również plastyczność, szczelność oraz brak reakcji chemicznych z gazem ziemnym.

Do tworzenia magazynów gazu w warstwach soli wykorzystywać można wyeksploatowane wcześniej kopalnie soli oraz czynne kopalnie, w których w czasie eksploatacji soli tworzą się komory spełniające wszystkie wymagania dla komór magazynowych. Są nimi m.in.:

- odpowiednia głębokość komory $(700 \div 2000 \mathrm{~m})$,

- odpowiednia średnica odwiertu kawernowego (kolumna eksploatacyjna powinna mieć od $95 / 8$ " do $133 / 8$ ),

- pełna szczelność odwiertu i komory magazynowej (sprawdzana po wykonaniu odwiertu i przed pierwszym napełnieniem gazem).

Kawernowe magazyny gazu zlokalizowane są w pokładach solnych o odpowiedniej miąższości albo w wysadach solnych. Podczas tworzenia kawern uzyskiwaną solankę zrzuca się bezpośrednio do morza lub przerabia w zakładzie chemicznym.

Budowę komory magazynowej rozpoczyna się od odwiercenia otworu w celu zbadania próbek skał (soli) oraz ustalenia głębokości posadowienia komory. Rozpoznanie złoża wykonuje się przy użyciu georadaru (GPR - ang. ground penetrating radar), który za pomocą nadajnika wzbudza fale elektromagnetyczne w głąb ośrodka skalnego. Wędrująca fala odbija się i wraca ze zmienioną długością i częstotliwością. Otrzymany w ten sposób obraz poddawany jest następnie analizie. Interpretacja otrzymanych wyników pozwala poznać budowę wgłębną ośrodka skalnego i wpływa na wyeliminowanie niepożądanych stref anhydrytów i łatwo rozpuszczalnych soli potasowo-magnezowych. Zabieg ten pozwala uniknąć w późniejszym czasie niekorzystnego kształtu komory. Kolejnym etapem jest instalacja i cementowanie rur eksploatacyjnych do głębokości około $30 \mathrm{~m}$ powyżej planowanego stropu komory. Następnie w otworze umieszcza się dwie współśrodkowe kolumny rur ługowniczych, których wylot zaopatrzony jest w specjalną głowicę.

Proces tworzenia komory polega na wtłaczaniu wody do otworu, stopniowym rozpuszczaniu soli i odbiorze solanki (rysunek 1). Strop otworu chroniony jest przez zastosowanie medium izolującego. Proces ługowania prowadzi się od dołu ku górze, przy stopniowym podnoszeniu kolumny rur ługowniczych oraz jednoczesnej izolacji stropu. W poszczególnych fazach tworzenia komory informacje o jej kształcie

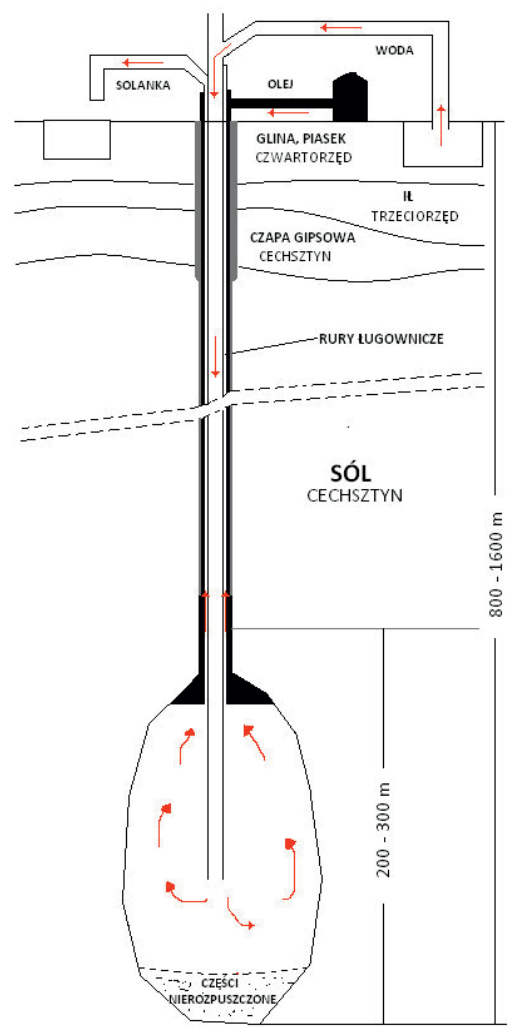

Rys. 1. Schemat procesu tworzenia komory w pokładach soli

i objętości można uzyskać przy użyciu specjalnej echosondy zapuszczanej na kablu do otworu.

Po utworzeniu całej komory i sprawdzeniu jej szczelności można przystąpić do procesu pierwszego napełniania.

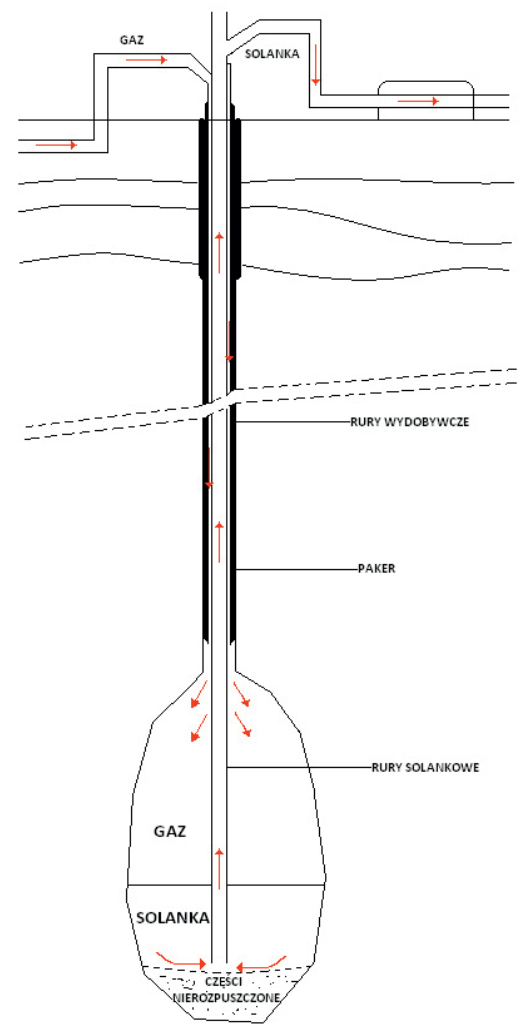

Rys. 2. Schemat procesu napełniania kawerny solnej 
Proces napełniania kawerny polega na zastąpieniu znajdującej się w komorze solanki gazem ziemnym oraz uzbrojeniu otworu wszystkimi niezbędnymi elementami (rysunek 2).

Po raz pierwszy magazyny gazu w pokładach soli zastosowano w 1961 r. w USA w stanie Michigan. W Europie pod względem ilości i pojemności KPMG (kawernowe podziemne magazyny gazu) prym wiodą Niemcy oraz Francja. W Polsce na dzień dzisiejszy istnieją dwa główne magazyny gazu w kawernach solnych: Mogilno (planowana pojemność około $800 \mathrm{mln} \mathrm{m}^{3}$ w 2018 r.) i Kosakowo (planowana pojemność około $250 \mathrm{mln} \mathrm{m}^{3} \mathrm{w} 2020 \mathrm{r}$.).

Ze względu na przeznaczenie i zastosowanie zaczynów cementowych w bezpośrednim środowisku soli oraz warunki geologiczne, jakie mogą panować w otworze wiertniczym, wykorzystane podczas uszczelniania kolumn rur okładzinowych zaczyny cementowe powinny spełniać następujące kryteria:
- do sporządzania zaczynu cementowego jako ciecz zarobową powinno się zastosować solankę o pełnym nasyceniu (gęstość 1,2 g/ $\mathrm{cm}^{3}$ ), ze względu na bezpośrednią obecność soli w otworze,

- zaczyn cementowy powinien posiadać odpowiednią reologię (zapewniającą jego przetłaczalność) oraz czas gęstnienia (czas końca gęstnienia, czyli momentu, po którym zaczyn przestaje być przetłaczany, powinien być dłuższy od czasu potrzebnego na zatłoczenie danego zaczynu do otworu),

- powstały po związaniu zaczynu kamień cementowy powinien być odporny na niekorzystne działanie soli w czasie oraz posiadać wysokie parametry mechaniczne;

- zastosowany zaczyn cementowy powinien odznaczać się dodatnimi zmianami objętości (odznaczać się pęcznieniem) ze względu na elastyczność pokładów soli $[1,2,3,4,7,9,10]$.

\section{Badania laboratoryjne}

W artykule zamieszczono wyniki badań 4 wybranych składów zaczynów cementowych, dla których uzyskano najlepsze rezultaty. Jako wody zarobowej użyto solanki o pełnym nasyceniu (solanka $\mathrm{NaCl}$ o gęstości $1,2 \mathrm{~g} / \mathrm{cm}^{3}$ ). W badaniach wykorzystano dwa rodzaje cementu, mikrocement, gips modelowy (dodawany do zaczynu cementowego w celu zapobiegania jego skurczowi, a jednocześnie powodujący jego pęcznienie) oraz inne dodatki wpływające na parametry reologiczne, czas gęstnienia, wiązanie zaczynów oraz parametry mechaniczne powstałych z nich kamieni cementowych. Do solanki dodawano kolejno środek odpieniający, upłynniający i obniżający filtrację oraz środki regulujące czasy gęstnienia i wiązania. Pozostałe składniki: mikrocement, gips modelowy oraz cement mieszano ze sobą i wprowadzano następnie do wody zarobowej. Odpowiednia głębokość występowania komory w soli wynosi od $700 \mathrm{~m}$ do $2000 \mathrm{~m}$, dlatego badania przeprowadzono dla dwóch różnych wytypowanych warunków otworowych, jakie mogą występować na tej głębokości:

1) temperatura $40^{\circ} \mathrm{C}$ i ciśnienie $20 \mathrm{MPa}$,

2) temperatura $60^{\circ} \mathrm{C}$ i ciśnienie $30 \mathrm{MPa}$.

Po sporządzeniu zaczynów cementowych mierzono ich:

- gęstość,

- rozlewność,

- parametry reologiczne,

- odstój wody,

- filtrację,

- czas gęstnienia,

- czas wiązania,

- pęcznienie.
Z opracowanych i zbadanych zaczynów cementowych sporządzono następnie próbki kamieni cementowych. Próbki utwardzano przez 48 godz. w środowisku o określonej temperaturze i ciśnieniu (warunki otworopodobne). Następnie umieszczano je w autoklawach wykonanych ze stali nierdzewnej, zalewano solanką i przez cały okres sezonowania przetrzymywano w cieplarce.

Otrzymane próbki kamieni cementowych poddawano badaniu:

- wytrzymałości na ściskanie

- wytrzymałości na zginanie

- przyczepności do rur stalowych,

- porowatości,

- przepuszczalności dla gazu.

Gęstość badanych zaczynów cementowych wahała się w przedziale od $1,82 \mathrm{~g} / \mathrm{cm}^{3}$ do $1,93 \mathrm{~g} / \mathrm{cm}^{3}$. Trzy zaczyny nie wykazały odstoju wody poza jednym, którego odstój wody wyniósł 1\% (skład nr 3). Poniżej przedstawiono szczegółowe wyniki badań właściwości reologicznych zaczynów cementowych oraz zmieniających się w czasie parametrów mechanicznych kamieni cementowych.

Niepewność uzyskanych wyników pomiarów zaprezentowanych poniżej oznaczono na podstawie klasy dokładności urządzeń pomiarowych na poziomie: dla pomiarów reologicznych - 0,2\%, dla pomiarów wytrzymałości na ściskanie, zginanie, przyczepność do rur - $0,4 \%$, dla porowatości - 0,0001\%, dla przepuszczalności - 0,001\%.

Wszystkie składniki zawarte w składach zaczynów cementowych dodawane były w stosunku procentowym do masy suchego cementu. 


\section{Zaczyn cementowy nr 1}

\begin{tabular}{|l|c|}
\hline \multicolumn{2}{|c|}{ Skład zaczynu nr 1} \\
\hline Solanka NaCl o gęstości $1,2 \mathrm{~g} / \mathrm{cm}^{3}$ & w/c $=\mathbf{0 , 6 0}$ \\
Odpieniacz & $0,5 \%$ \\
Upłynniacz & $0,5 \%$ \\
Antyfiltrat & $0,1 \%$ \\
$\mathrm{CaCl}_{2}$ & $0,7 \%$ \\
$\mathrm{Mikrocement}_{\text {Cement CEM II B/V 42,5 }}$ & $\mathbf{8 , 0 \%}$ \\
Gips modelowy & $100 \%$ \\
Środek spęczniający & $\mathbf{5 , 0 \%}$ \\
\hline
\end{tabular}

Zaczyn cementowy nr $1 \mathrm{w}$ swoim składzie zawierał m.in. cement CEM II B/V 42,5, mikrocement - 8,0\%, gips modelowy $-5,0 \%$. Gęstość zaczynu cementowego wynosiła
$1,84 \mathrm{~g} / \mathrm{cm}^{3}$. Nie wykazał on odstoju wody. Rozlewność zaczynu nr 1 była równa $170 \mathrm{~mm}$. Początek gęstnienia nastąpił po czasie 2 godz. $44 \mathrm{~min}$, a koniec po 6 godz. $47 \mathrm{~min}$. Pęcznienie zaczynu cementowego po 24 godz. wyniosło: $+0,137$, a po 48 godz.: $+0,141 \%$.

Wytrzymałość kamienia cementowego na ściskanie po 2 i 7 dniach wynosiła około 14,0 MPa, następnie wzrosła i po 28 dniach utrzymywała się na poziomie $36 \mathrm{MPa}$. Przyczepność kamienia do rur stalowych po każdym okresie badania była coraz wyższa, zaś jego wytrzymałość na zginanie przez cały okres sezonowania próbek nie uległa zmianie. Porowatość kamienia cementowego wraz z upływem czasu była coraz niższa i po 28 dniach wyniosła $30,1 \%$, a przepuszczalność dla gazu po każdym badaniu nie przekraczała $0,4 \mathrm{mD}$ (tablica 1 i 2 ).

Tablica 1. Parametry reologiczne zaczynu cementowego 1

\begin{tabular}{|c|c|c|c|}
\hline \multicolumn{2}{|c|}{ Rozlewność [mm] } & \multicolumn{2}{|c|}{170} \\
\hline \multicolumn{2}{|c|}{ Gęstość [g/cm³] } & \multicolumn{2}{|c|}{1,84} \\
\hline \multicolumn{2}{|c|}{ Odstój wody [\%] } & \multicolumn{2}{|c|}{0,0} \\
\hline \multirow{8}{*}{$\begin{array}{c}\text { Odczyty } \\
\text { z aparatu } \\
\text { Fann } \\
\text { [obr./min] }\end{array}$} & 600 & \multicolumn{2}{|c|}{289} \\
\hline & 300 & \multicolumn{2}{|c|}{189} \\
\hline & 200 & \multicolumn{2}{|c|}{131} \\
\hline & 100 & \multicolumn{2}{|c|}{88} \\
\hline & 60 & \multicolumn{2}{|c|}{70} \\
\hline & 30 & \multicolumn{2}{|c|}{55} \\
\hline & 6 & \multicolumn{2}{|c|}{37} \\
\hline & 3 & \multicolumn{2}{|c|}{27} \\
\hline \multicolumn{2}{|c|}{ Lepkość plastyczna $[\mathrm{mPa} \cdot \mathrm{s}]$} & \multicolumn{2}{|c|}{151,5} \\
\hline \multicolumn{2}{|c|}{ Granica płynięcia [Pa] } & \multicolumn{2}{|c|}{18,0} \\
\hline \multirow{2}{*}{\multicolumn{2}{|c|}{$\begin{array}{l}\text { Czas gęstnienia [h-min], } \\
40^{\circ} \mathrm{C}, 20 \mathrm{MPa}\end{array}$}} & $30 \mathrm{Bc}$ & $100 \mathrm{Bc}$ \\
\hline & & $2-44$ & $6-47$ \\
\hline \multicolumn{2}{|c|}{ Filtracja $\left[\mathrm{cm}^{3} / 30 \mathrm{~min}\right]$} & \multicolumn{2}{|c|}{$>600$} \\
\hline
\end{tabular}

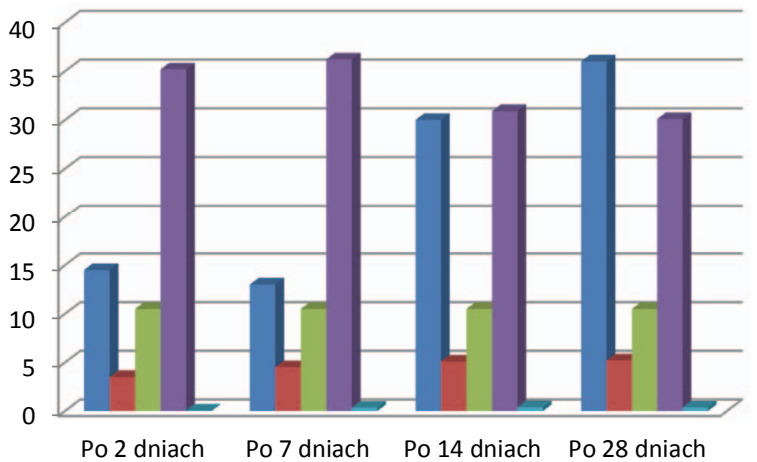

Rys. 1. Parametry mechaniczne próbki 1
- Ściskanie [MPa] - Przyczepność [MPa] Zginanie [MPa] 口 Porowatość [\%] - Przepuszczalność [mD]

Tablica 2. Parametry mechaniczne kamienia cementowego 1

\begin{tabular}{|l|c|c|c|c|c|}
\cline { 3 - 6 } \multicolumn{1}{l|}{} & $\begin{array}{c}\text { Temperatura } \\
{\left[{ }^{\circ} \mathrm{C}\right]}\end{array}$ & Po 2 dniach & Po 7 dniach & Po 14 dniach & Po 28 dniach \\
\hline Wytrzymałość na ściskanie [MPa] & & 14,5 & 13,0 & 30,0 & 36,0 \\
\hline Przyczepność do rur [MPa] & \multirow{2}{*}{40} & 3,5 & 4,5 & 5,1 & 5,2 \\
\hline Wytrzymałość na zginanie [MPa] & & 10,5 & 10,5 & 10,5 & 10,5 \\
\hline Porowatość [\%] & & 35,2 & 36,2 & 30,9 & 30,1 \\
\hline Przepuszczalność [mD] & & 0,06 & 0,35 & 0,40 & 0,37 \\
\hline
\end{tabular}




\section{Zaczyn cementowy nr 2}

\begin{tabular}{|l|c|}
\hline \multicolumn{2}{|c|}{ Skład zaczynu nr 2} \\
\hline Solanka NaCl o gęstości 1,2 g/cm & w/c = 0,62 \\
Odpieniacz & $0,5 \%$ \\
Upłynniacz & $0,5 \%$ \\
Antyfiltrat & $0,1 \%$ \\
$\mathrm{CaCl}_{2}$ & $0,5 \%$ \\
Lateks $_{\text {Mikrocement }}$ & $5,0 \%$ \\
Cement CEM II B/V 42,5 & $\mathbf{8 , 0 \%}$ \\
Gips modelowy & $100 \%$ \\
Środek spęczniający & $\mathbf{8 , 0 \%}$ \\
\hline
\end{tabular}

W składzie nr 2 zastosowano również cement CEM II B/V 42,5 i 8,0\% mikrocementu (jak w składzie nr 1). Zwiększona została natomiast ilość dodanego gipsu do 8,0\%. Dodano również 5\% lateksu w celu obniżenia filtracji zaczynu cementowego. Gęstość zaczynu wyniosła $1,82 \mathrm{~g} / \mathrm{cm}^{3}$.
Nie wykazał on odstoju wody. Początek gęstnienia zaczynu nr 2 nastąpił po czasie 3 godz. $57 \mathrm{~min}$, a koniec gęstnienia po 5 godz. 56 min. Zaczyn posiadał dodatnie zmiany objętości, które po 24 godz. i 48 godz. wyniosły odpowiednio: $+0,143 \%$ $\mathrm{i}+0,145 \%$. Zastosowanie dodatku lateksu w zaczynie nr 2 nie wpłynęło na osiągnięcie zamierzonego celu i zbadana filtracja była w dalszym ciągu większa od $600 \mathrm{~cm}^{3} / 30 \mathrm{~min}$.

Wytrzymałość kamienia cementowego na ściskanie otrzymanego ze składu nr 2 po 2 dniach wyniosła 9,8 MPa. Następnie z upływem czasu jej wartość wzrastała i po 28 dniach była na poziomie 27,8 PMa. Przyczepność kamienia do rur stalowych z upływem czasu nie ulegała większym zmianom, natomiast jego wytrzymałość na zginanie przez cały okres sezonowania próbek wzrastała. Porowatość kamienia cementowego po 2 dniach była wysoka i wyniosła 38,4\%. W późniejszym okresie porowatość nieznacznie zmalała. Przepuszczalność dla gazu posiadała wartości niższe od $0,47 \mathrm{mD}$ (tablica 3 i 4 ).

Tablica 3. Parametry reologiczne zaczynu cementowego 2

\begin{tabular}{|c|c|c|c|}
\hline \multicolumn{2}{|c|}{ Rozlewność [mm] } & \multicolumn{2}{|c|}{150} \\
\hline \multicolumn{2}{|c|}{ Gęstość $\left[\mathrm{g} / \mathrm{cm}^{3}\right]$} & \multicolumn{2}{|c|}{1,82} \\
\hline \multicolumn{2}{|c|}{ Odstój wody [\%] } & \multicolumn{2}{|c|}{0,0} \\
\hline \multirow{8}{*}{$\begin{array}{c}\text { Odczyty } \\
\text { z aparatu } \\
\text { Fann } \\
\text { [obr./min] }\end{array}$} & 600 & \multicolumn{2}{|c|}{$>300$} \\
\hline & 300 & \multicolumn{2}{|c|}{226} \\
\hline & 200 & \multicolumn{2}{|c|}{171} \\
\hline & 100 & \multicolumn{2}{|c|}{114} \\
\hline & 60 & \multicolumn{2}{|c|}{89} \\
\hline & 30 & \multicolumn{2}{|c|}{69} \\
\hline & 6 & \multicolumn{2}{|c|}{42} \\
\hline & 3 & \multicolumn{2}{|c|}{32} \\
\hline \multicolumn{2}{|c|}{ Lepkość plastyczna $[\mathrm{mPa} \cdot \mathrm{s}]$} & \multicolumn{2}{|c|}{168,0} \\
\hline \multicolumn{2}{|c|}{ Granica płynięcia $[\mathrm{Pa}]$} & \multicolumn{2}{|c|}{27,8} \\
\hline \multirow{2}{*}{\multicolumn{2}{|c|}{$\begin{array}{l}\text { Czas gęstnienia [h-min], } \\
40^{\circ} \mathrm{C}, 20 \mathrm{MPa}\end{array}$}} & $30 \mathrm{Bc}$ & $100 \mathrm{Bc}$ \\
\hline & & $3-57$ & $5-56$ \\
\hline \multicolumn{2}{|c|}{ Filtracja $\left[\mathrm{cm}^{3} / 30 \mathrm{~min}\right]$} & \multicolumn{2}{|c|}{$>600$} \\
\hline
\end{tabular}

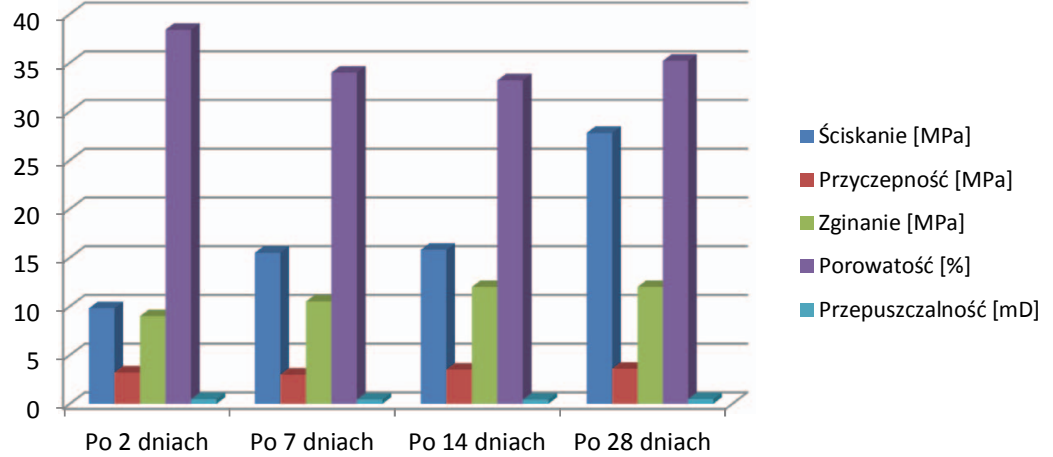

Rys. 2. Parametry mechaniczne próbki 2

Tablica 4. Parametry mechaniczne kamienia cementowego 2

\begin{tabular}{|l|c|c|c|c|c|}
\cline { 3 - 6 } \multicolumn{1}{l|}{} & $\begin{array}{c}\text { Temperatura } \\
{\left[{ }^{\circ} \mathrm{C}\right]}\end{array}$ & Po 2 dniach & Po 7 dniach & Po 14 dniach & Po 28 dniach \\
\hline Wytrzymałość na ściskanie [MPa] & & 9,8 & 15,5 & 15,8 & 27,8 \\
\hline Przyczepność do rur [MPa] & \multirow{2}{*}{40} & 3,2 & 3,0 & 3,5 & 3,6 \\
\hline Wytrzymałość na zginanie [MPa] & & 9,0 & 10,5 & 12,0 & 12,0 \\
\hline Porowatość [\%] & & 38,4 & 34,0 & 33,2 & 35,2 \\
\hline Przepuszczalność [mD] & & 0,46 & 0,43 & 0,42 & 0,47 \\
\hline
\end{tabular}




\section{Zaczyn cementowy nr 3}

\begin{tabular}{|l|c|}
\hline \multicolumn{2}{|c|}{ Skład zaczynu nr 3} \\
\hline Solanka NaCl o gęstości $1,2 \mathrm{~g} / \mathrm{cm}^{3}$ & $\mathbf{w} / \mathbf{c}=\mathbf{0 , 6 0}$ \\
Odpieniacz & $0,5 \%$ \\
Upłynniacz & $0,5 \%$ \\
Antyfiltrat & $0,1 \%$ \\
Mikrocement & $\mathbf{1 0 , 0 \%}$ \\
Cement G & $100 \%$ \\
Gips modelowy & $\mathbf{1 0 , 0 \%}$ \\
Środek spęczniający & $0,2 \%$ \\
\hline
\end{tabular}

W składzie zaczynu cementowego nr 3 zastosowano cement $\mathrm{G}$ oraz mikrocement i gips modelowy w ilościach po
$10,0 \%$ każdy. Zaczyn posiadał gęstość $1,93 \mathrm{~g} / \mathrm{cm}^{3}$ oraz miał $1 \%$ odstoju wody. Jego rozlewność wyniosła $160 \mathrm{~mm}$. Po czasie 6 godz. 30 min konsystencja zaczynu nr 3 była równa 12 Bc. Pomiary pęcznienia wykazały dodatnie zmiany objętości w czasie, które wyniosły: $+0,148 \%$ po 24 godz. $\mathrm{i}+0,152 \%$ po 48 godz.

Wartości wytrzymałości na ściskanie, zginanie oraz przyczepności do rur kamienia cementowego wykonanego z zaczynu nr 3 przez cały okres sezonowania próbek wykazywały tendencję wzrostową. Porowatość kamienia cementowego do 28 dni nie przekraczała 34,0\%. Przepuszczalność dla gazu kamienia nie przekraczała $0,46 \mathrm{mD}$ (tablica 5 i 6 ).

Tablica 5. Parametry reologiczne zaczynu cementowego 3

\begin{tabular}{|c|c|c|c|}
\hline \multicolumn{2}{|c|}{ Rozlewność [mm] } & \multicolumn{2}{|c|}{160} \\
\hline \multicolumn{2}{|c|}{ Gęstość $\left[\mathrm{g} / \mathrm{cm}^{3}\right]$} & \multicolumn{2}{|c|}{1,93} \\
\hline \multicolumn{2}{|c|}{ Odstój wody [\%] } & \multicolumn{2}{|c|}{1,0} \\
\hline \multirow{8}{*}{$\begin{array}{c}\text { Odczyty } \\
\text { z aparatu } \\
\text { Fann } \\
\text { [obr./min] }\end{array}$} & 600 & \multicolumn{2}{|c|}{231} \\
\hline & 300 & \multicolumn{2}{|c|}{144} \\
\hline & 200 & \multicolumn{2}{|c|}{119} \\
\hline & 100 & \multicolumn{2}{|c|}{71} \\
\hline & 60 & \multicolumn{2}{|c|}{55} \\
\hline & 30 & \multicolumn{2}{|c|}{43} \\
\hline & 6 & \multicolumn{2}{|c|}{29} \\
\hline & 3 & \multicolumn{2}{|c|}{24} \\
\hline \multicolumn{2}{|c|}{ Lepkość plastyczna $[\mathrm{mPa} \cdot \mathrm{s}]$} & \multicolumn{2}{|c|}{109,5} \\
\hline \multicolumn{2}{|c|}{ Granica płynięcia [Pa] } & \multicolumn{2}{|c|}{16,6} \\
\hline \multirow{2}{*}{\multicolumn{2}{|c|}{$\begin{array}{l}\text { Czas gęstnienia [h-min], } \\
60^{\circ} \mathrm{C}, 30 \mathrm{MPa}\end{array}$}} & $12 \mathrm{Bc}$ & $100 \mathrm{Bc}$ \\
\hline & & $6-30$ & - \\
\hline \multicolumn{2}{|c|}{ Filtracja $\left[\mathrm{cm}^{3} / 30 \mathrm{~min}\right]$} & \multicolumn{2}{|c|}{$>600$} \\
\hline
\end{tabular}

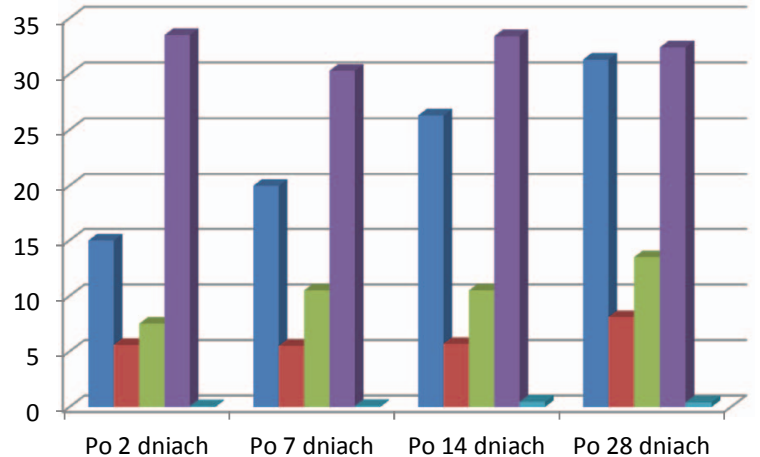

Rys. 3. Parametry mechaniczne próbki 3
- Ściskanie [MPa] - Przyczepność [MPa] Zginanie [MPa] - Porowatość [\%] n Przepuszczalność [mD]

Tablica 6. Parametry mechaniczne kamienia cementowego 3

\begin{tabular}{|c|c|c|c|c|c|}
\hline & $\begin{array}{c}\text { Temperatura } \\
{\left[{ }^{\circ} \mathrm{C}\right]}\end{array}$ & Po 2 dniach & Po 7 dniach & Po 14 dniach & Po 28 dniach \\
\hline Wytrzymałość na ściskanie [MPa] & \multirow{5}{*}{60} & 15,0 & 20,0 & 26,3 & 31,3 \\
\hline Przyczepność do rur [MPa] & & 5,6 & 5,5 & 5,7 & 8,1 \\
\hline Wytrzymałość na zginanie [MPa] & & 7,5 & 10,5 & 10,5 & 13,5 \\
\hline Porowatość [\%] & & 33,5 & 30,3 & 33,4 & 32,4 \\
\hline Przepuszczalność [mD] & & 0,08 & 0,10 & 0,46 & 0,42 \\
\hline
\end{tabular}




\section{Zaczyn cementowy nr 4}

\begin{tabular}{|l|c|}
\hline \multicolumn{2}{|c|}{ Skład zaczynu nr 4} \\
\hline Solanka NaCl o gęstości 1,2 g/cm $\mathrm{cm}^{3}$ & $\mathbf{w} / \mathbf{c}=\mathbf{0 , 6 2}$ \\
Odpieniacz & $0,5 \%$ \\
Upłynniacz & $0,5 \%$ \\
Antyfiltrat & $0,1 \%$ \\
Opóźniacz & $0,4 \%$ \\
Mikrocement & $\mathbf{1 0 , 0 \%}$ \\
Cement CEM II B/V 42,5 & $100 \%$ \\
Gips modelowy & $\mathbf{5 , 0 \%}$ \\
Środek spęczniający & $0,2 \%$ \\
\hline
\end{tabular}

Zaczyn cementowy nr 4 został sporządzony na bazie cementu CEM II B/V 42,5 z dodatkiem 10\% mikrocementu. Ze względu na zmianę cementu w porównaniu do składu nr 3 (cement G) i jego większą powierzchnię właściwą zmniejszono ilość dodanego gipsu do 5\%. Zaczyn posiadał gęstość $1,87 \mathrm{~g} / \mathrm{cm}^{3}$. Nie wykazał on odstoju wody. Rozlewność zaczynu wyniosła $180 \mathrm{~mm}$. Początek gęstnienia osiągnął po czasie 2 godz. $22 \mathrm{~min}$, a koniec gęstnienia po 3 godz. 45 min. Czasy początku i końca wiązania zaczynu cementowego wynosiły odpowiednio 5 godz. i 6 godz. 15 min. Wprowadzenie do jego składu gipsu modelowego również w tym przypadku wpłynęło na dodatnie zmiany objętości. Po 24 godz. pęcznienie wyniosło: $+0,139 \%$, a po 48 godz. $+0,144 \%$.

Wartości wytrzymałości na ściskanie oraz przyczepności do rur kamienia cementowego nr 4 przez cały okres badań wzrastały. Porowatość kamienia cementowego przez cały okres jego deponowania utrzymywała się na poziomie od $30 \%$ do $32 \%$, a przepuszczalność dla gazu nie przekraczała $0,5 \mathrm{mD}$ (tablica 7 i 8 ).

Tablica 7. Parametry reologiczne zaczynu cementowego 4

\begin{tabular}{|c|c|c|c|}
\hline \multicolumn{2}{|c|}{ Rozlewność [mm] } & \multicolumn{2}{|c|}{180} \\
\hline \multicolumn{2}{|c|}{ Gęstość $\left[\mathrm{g} / \mathrm{cm}^{3}\right]$} & \multicolumn{2}{|c|}{1,87} \\
\hline \multicolumn{2}{|c|}{ Odstój wody [\%] } & \multicolumn{2}{|c|}{0,0} \\
\hline \multirow{8}{*}{$\begin{array}{c}\text { Odczyty } \\
\text { z aparatu } \\
\text { Fann } \\
\text { [obr./min] }\end{array}$} & 600 & \multicolumn{2}{|c|}{290} \\
\hline & 300 & \multicolumn{2}{|c|}{171} \\
\hline & 200 & \multicolumn{2}{|c|}{131} \\
\hline & 100 & \multicolumn{2}{|c|}{90} \\
\hline & 60 & \multicolumn{2}{|c|}{72} \\
\hline & 30 & \multicolumn{2}{|c|}{58} \\
\hline & 6 & \multicolumn{2}{|c|}{38} \\
\hline & 3 & \multicolumn{2}{|c|}{26} \\
\hline \multicolumn{2}{|c|}{ Lepkość plastyczna $[\mathrm{mPa} \cdot \mathrm{s}]$} & \multicolumn{2}{|c|}{121,5} \\
\hline \multicolumn{2}{|c|}{ Granica płynięcia $[\mathrm{Pa}]$} & \multicolumn{2}{|c|}{23,8} \\
\hline \multirow{2}{*}{\multicolumn{2}{|c|}{$\begin{array}{l}\text { Czas gęstnienia [h-min], } \\
60^{\circ} \mathrm{C}, 30 \mathrm{MPa}\end{array}$}} & $30 \mathrm{Bc}$ & $100 \mathrm{Bc}$ \\
\hline & & $2-22$ & $3-45$ \\
\hline \multicolumn{2}{|c|}{ Filtracja $\left[\mathrm{cm}^{3} / 30 \mathrm{~min}\right]$} & \multicolumn{2}{|c|}{$>600$} \\
\hline
\end{tabular}

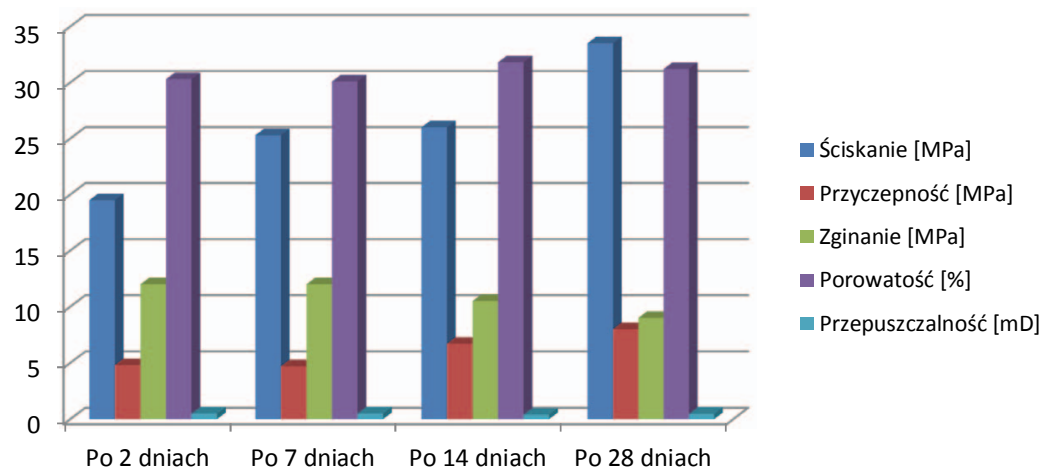

Rys. 4. Parametry mechaniczne próbki 4

Tablica 8. Parametry mechaniczne kamienia cementowego 4

\begin{tabular}{|l|c|c|c|c|c|}
\cline { 3 - 6 } \multicolumn{1}{l|}{} & $\begin{array}{c}\text { Temperatura } \\
{\left[{ }^{\circ} \mathrm{C}\right]}\end{array}$ & Po 2 dniach & Po 7 dniach & Po 14 dniach & Po 28 dniach \\
\hline Wytrzymałość na ściskanie [MPa] & & 19,5 & 25,3 & 26,0 & 33,5 \\
\hline Przyczepność do rur [MPa] & \multirow{2}{*}{60} & 4,8 & 4,7 & 6,7 & 8,0 \\
\hline Wytrzymałość na zginanie [MPa] & \multirow{2}{*}{60,0} & 12,0 & 10,5 & 9,0 \\
\hline Porowatość [\%] & & 30,3 & 30,1 & 31,8 & 31,2 \\
\hline Przepuszczalność [mD] & & 0,49 & 0,50 & 0,40 & 0,46 \\
\hline
\end{tabular}


Parametry technologiczne zaczynów cementowych proponowanych do zastosowania podczas uszczelniania ko- lumn rur okładzinowych w pokładach solnych zestawiono w tablicy $\mathrm{nr} 9$.

Tablica 9. Zestawienie najważniejszych wyników zaczynów i kamieni cementowych

\begin{tabular}{|c|c|c|c|c|c|c|c|c|c|}
\hline \multirow[t]{2}{*}{$\begin{array}{c}\text { Temperatura } \\
{\left[{ }^{\circ} \mathrm{C}\right]}\end{array}$} & \multirow[t]{2}{*}{ Nr zaczynu } & \multirow[t]{2}{*}{$\begin{array}{l}\text { Gęstość } \\
{\left[\mathrm{g} / \mathrm{cm}^{3}\right]}\end{array}$} & \multirow[t]{2}{*}{$\begin{array}{c}\text { Rozlewność } \\
{[\mathrm{mm}]}\end{array}$} & \multirow{2}{*}{$\begin{array}{c}\text { Lepkość } \\
\text { plastyczna } \\
{[\mathrm{mPa} \cdot \mathrm{s}]}\end{array}$} & \multirow{2}{*}{$\begin{array}{c}\text { Granica } \\
\text { płynięcia } \\
{[\mathrm{Pa}]}\end{array}$} & \multicolumn{2}{|c|}{$\begin{array}{c}\text { Czas gęstnienia } \\
\text { [h-min] }\end{array}$} & \multicolumn{2}{|c|}{$\begin{array}{c}\text { Wytrzymałość na } \\
\text { ściskanie } \\
\text { [MPa] }\end{array}$} \\
\hline & & & & & & $30 \mathrm{Bc}$ & $100 \mathrm{Bc}$ & $2 \mathrm{dni}$ & $28 \mathrm{dni}$ \\
\hline \multirow{2}{*}{$40^{\circ} \mathrm{C}$} & 1 & 1,84 & 170 & 151,5 & 18,0 & $2-44$ & $6-47$ & 14,5 & 36,0 \\
\hline & 2 & 1,82 & 150 & 168,0 & 27,8 & $3-57$ & $5-56$ & 9,8 & 27,8 \\
\hline \multirow{2}{*}{$60^{\circ} \mathrm{C}$} & 3 & 1,93 & 160 & 109,5 & 16,6 & - & - & 15,0 & 31,3 \\
\hline & 4 & 1,87 & 180 & 121,5 & 23,8 & $2-22$ & $3-45$ & 19,5 & 33,5 \\
\hline
\end{tabular}

\section{Wnioski}

Po przeprowadzeniu badań laboratoryjnych zasolonych zaczynów cementowych można wyciągnąc następujące wnioski:

1) Poddane badaniom składy zaczynów cementowych charakteryzowały się dobrymi parametrami reologicznymi oraz zerowym odstojem wody z wyjątkiem składu nr 3 (odstój wyniósł 1\%).

2) Gęstości zaczynów cementowych wahały się w przedziale od $1,82 \mathrm{~g} / \mathrm{cm}^{3}$ do $1,93 \mathrm{~g} / \mathrm{cm}^{3}$.

3) Wszystkie opracowane receptury posiadały wysoką filtrację przekraczającą $600,0 \mathrm{~cm}^{3} / 30 \mathrm{~min}$. Zastosowanie solanki o pełnym nasyceniu jako wody zarobowej neutralizowało działanie środka antyfiltracyjnego oraz lateksu dodawanego do zaczynów cementowych w celu ograniczania filtracji.

4) Zaczyn cementowy sporządzony na bazie cementu G po czasie 6 godz. 30 min nie osiągnął początku gęstnienia i utrzymywał konsystencję $12 \mathrm{Bc}-\mathrm{w}$ trakcie testów na konsystometrze HTHP,

5) Receptury opracowane na bazie cementu CEM II B/V 42,5 uzyskiwały czasy gęstnienia odpowiednie dla danych warunków otworowych, jakie mogą panować podczas ich zatłaczania do otworu. Czasy te można swobodnie regulować środkiem opóźniającym wiązanie.

6) Wszystkie zmierzone rozlewności mieściły się w przedziale od $150 \mathrm{~mm}$ do $180 \mathrm{~mm}$.

7) Każdy zaczyn cementowy posiadał dodatnie zmiany objętości, które mieściły się w przedziale od $+0,137 \%$ po 24 godz. (zaczyn nr 1) do $+0,152 \%$ po 48 godz. (zaczyn nr 3).

8) Parametry opracowanych składów zaczynów uszczelniających $w$ razie potrzeby można $z$ powodzeniem regulować, zmieniając ilości procentowe użytych dodatków.
9) Zastosowanie w składach zaczynów cementowych większych ilości dodatków $\mathrm{CaCl}_{2}$, lateksu i środka antyfiltracyjnego wpływało na zmniejszenie ich rozlewności oraz pogorszenie parametrów reologicznych.

10) Badania laboratoryjne parametrów mechanicznych kamieni cementowych przetrzymywanych w temperaturach $40^{\circ} \mathrm{C}$ i $60^{\circ} \mathrm{C}$ wykazały, że już po 2 dniach ich wytrzymałości na ściskanie przekraczały 14,0 MPa (z wyjątkiem składu nr 2), na zginanie - 7,0 MPa, a przyczepność do rur stalowych przekraczała 3,0 MPa.

11) Większość badanych próbek kamieni cementowych wraz z upływem czasu odznaczała się wzrostem parametrów mechanicznych.

12) Porowatości kamieni cementowych otrzymanych $z$ wytypowanych składów po 2 dniach wynosiły od 30,3\% (nr 4) do $38,4 \%$ (nr 2), zaś po 28 dniach od $30,1 \%$ (nr 1) do 35,2\% (nr 2).

13) Przepuszczalności dla gazu wszystkich kamieni cementowych przez cały okres ich sezonowania nie przekraczały $0,5 \mathrm{mD}$.

Przeprowadzone badania parametrów zaczynów cementowych oraz powstałych z nich kamieni cementowych powinny być pomocne przy typowaniu składów charakteryzujących się odpowiednimi właściwościami do specyficznych warunków geologicznych, jakie panują w pokładach solnych.

Uszczelnianie otworów wiertniczych, w szczególności w warstwach występowania pokładów soli, wymaga zastosowania zaczynów cementowych o podwyższonej odporności na jej działanie. Opracowane i wybrane składy dzięki swoim parametrom reologicznym oraz mechanicznym kamieni cementowych mogą być z powodzeniem stosowane podczas takich zabiegów. 
Prosimy cytować jako: Nafta-Gaz 2016, nr 4, s. 242-250, DOI: 10.18668/NG.2016.04.03

Artykuł nadesłano do Redakcji 23.11.2015 r. Zatwierdzono do druku 18.01.2016 r.

Artykuł powstał na podstawie pracy statutowej pt. Analiza właściwości technologicznych zaczynów cementowych do uszczelniania rur okładzinowych $w$ kawernowych magazynach gazu - praca INiG - PIB na zlecenie MNiSW, nr archiwalny: DK-4100-34/15, nr zlecenia 0034/KW/2015.

\section{Literatura}

[1] Dębińska E.: Ocena działania dodatków opóźniajacych czas wiązania zaczynów cementowych na podstawie badań laboratoryjnych. Nafta-Gaz 2012, nr 4, s. 225-232.

[2] Giergiczny Z. i in.: Cementy w ofercie handlowej Górażdze Cement S.A. Chorula, październik 2003.

[3] Kremieniewski M., Rzepka M.: Wptyw procesu ogrzewania na reologię modyfikowanych zaczynów cementowych. Nafta-Gaz 2009, nr 10, s. 775-781.

[4] Kurdowski W.: Chemia cementu i betonu. Warszawa, Wydawnictwo Naukowe PWN, 2010.

[5] Laskowska T.: Underground gas storage in salt caverns. Polish Market 2012, nr 9, s. 28-29.

[6] Laskowska T., Gąska K.: Nowe metody i technologie zastosowane $w$ czasie tugowania komór, przy budowie magazynów gazu zlokalizowanych w złożach soli. Nafta-Gaz 2010, nr 5, s. 356-361.

[7] Neville A. M.: Właściwości betonu. Wyd. 4. Kraków 2000.

[8] Stopa J., Rychlicki S., Kosowski P.: Rola podziemnego magazynowania gazu w kawernach solnych. Gospodarka Surowcami Mineralnymi 2008, t. 24, z. $3 / 2$.
[9] Storing natural gas underground. Oilfield Review, Summer 2002, https://www.slb.com/ /media/Files/resources/oilfield_review/ors02/sum02/p2_17.pdf (dostęp: 15.10.2015).

[10] Underground storage of natural gas, http://www.ipt.ntnu.no / jsg/undervisning/naturgass/parlaktuna/Chap9.pdf (dostęp: 19.10.2015)

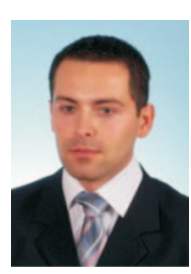

Mgr inż. Łukasz KUT

Asystent w Zakładzie Technologii Wiercenia. Instytut Nafty i Gazu - Państwowy Instytut Badawczy ul. Lubicz 25 A

31-503 Kraków

E-mail:lukasz.kut@inig.pl

\section{OFERTA}

\section{ZAKŁAD TECHNOLOGII WIERCENIA}

Zakres działania:

- $\quad$ opracowywanie składów i technologii sporzadzania płuczek wiertniczych, cieczy do dowiercania, opróbowania i rekonstrukcji odwiertów, zaczynów cementowych i mieszanin wiążących dla różnych warunków geologiczno-technicznych wiercenia;

- $\quad$ kompleksowe badania i ocena nowych rodzajów środków chemicznych, materiałów płuczkowych i wiążących, przeznaczonych do sporządzania i regulowania właściwości płuczek wiertniczych i zaczynów cementowych;

- $\quad$ pomiary parametrów technologicznych cieczy wiertniczych i kamienia cementowego w warunkach normalnej i wysokiej temperatury oraz ciśnienia;

- $\quad$ badania wpływu płuczek wiertniczych na przewiercane skały;

- dobór płuczek wiertniczych, zaczynów cementowych, cieczy buforowych w celu poprawy skuteczności cementowania otworów wiertniczych;

- badania serwisowe dla bieżacych zabiegów cementowania

- $\quad$ specjalistyczne badania laboratoryjne dotyczące oznaczania: współczynnika tarcia cieczy wiertniczych i napięcia powierzchniowego na granicy faz, czystości i temperatury krystalizacji solanek, typu emulsji, sedymentacji fazy stałej, efektywności wynoszenia zwiercin w otworach kierunkowych i poziomych oraz wypłukiwania osadów iłowych ze skał przed zabiegiem cementowania, odporności na migrację gazu w wiążącym zaczynie cementowym w warunkach otworopodobnych, wczesnej wytrzymałości na ściskanie kamienia cementowego, odporności korozyjnej kamienia cementowego w różnym środowisku złożowym, porowatości oraz przepuszczalności dla gazu kamienia cementowego i skał, zawartości związków chemicznych w cieczach wiertniczych, stopnia toksyczności środków chemicznych i cieczy wiertniczych przy użyciu bakterii bioindykatorów;

- $\quad$ badania właściwości fizyczno-mechanicznych skał pod kątem ich zwiercalności.

Kierownik: dr inż. Małgorzata Uliasz Adres: ul. Armii Krajowej 3, 38-400 Krosno

Telefon: 13 436-89-41 w. 5219

Faks: 13 436-79-71

E-mail: malgorzata.uliasz@inig.pl

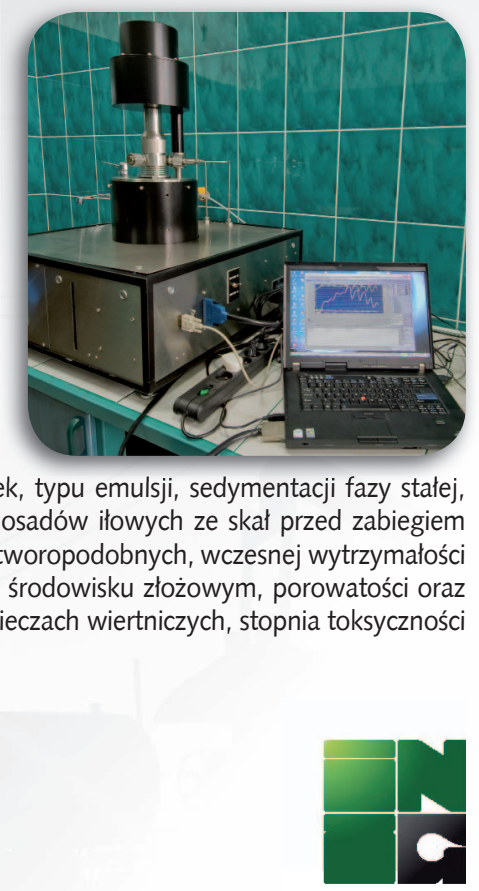

